\title{
The implementation of guided discovery learning method to improve student learning outcomes at electromagnetic control system and operation course
}

\author{
Aswardi \\ Universitas Negeri Padang \\ ${ }^{*}$ Corresponding author, $\equiv$ e-mail: aswardi@ft.unp.ac.id
}

\begin{abstract}
This research is triggered by the learning process that is still yet to direct the active role of students learning. Based on the result of observation that the teacher is more dominant in the activity of learning than the students due to the students were lack of understanding towards the subject matter resulted in the lack of activeness of students in the classroom. Based on the background study, it is needed to apply a method of learning that can enhance students' activity and improving the score. One of them by applied the guided discovery learning method. The goal of this research is to know the learning outcome's improvement of the students when using guided discovery learning method on operated Electromagnetic Control System and Operation course in SMK Muhammadiyah Padang. The type of this research is quasi-experimental with one group pre-test post-test design. The population of this research was a second-year student of group one that registered at 2015/2016 academic year which 26 people of students. The instrument of research was objective tests that have been conducted a test on the validity, reliability, the difficulty level and the different index level. The data were analyzed by using gain score test. Based on the result, the student who achieve value of minimum completeness criteria (MCC) before using the guided discovery learning method was $7,7 \%$. While the students who achieve minimum completeness criteria after using guided discovery learning method was $87,46 \%$. Based on gained score test, the scores than the students were increased in Middle Category. So, the implementation of guided discovery learning method can improve student learning outcomes on Electromagnetic Control System and Operation courses.
\end{abstract}

Keywords: Guided Discovery Learning Method, Improving Student Learning Outcomes, Gain Score Test

How to Cite: Aswardi. (2017). The implementation of guided discovery learning method to improve student learning outcomes at electromagnetic control system and operation course. Couns-Edu: International Journal of Counseling and Education, 2(2): pp. 85-91. DOI: https://doi.org/10.23916/0020170210520

\section{Introduction}

Education is essentially very important for requirement and cannot be separated from human life. This means that every human being has the right to education and will be expected to flourish in it. It can be reached formal education, non-formal and informal. Vocational High School as one of the formal educational institutions plays an important role in increasing resources as a nation. 
Secondary vocational schools have close links with business and industry that aim to prepare graduates or mid-level personnel that are ready to face the world of work who have the knowledge, skills and are able to develop a professional attitude in accordance with the specifications of its vocational.

SMK Muhammadiyah 1 Padang also carries out various activities and formal educational activities with the aim of realizing the achievement of its graduates. This school has a variety of programs tailored to the competency skill to be achieved. Program membership is composed of several subjects, including the Operating Electromagnetic Control System (OECS).

OECS is the subject to educate, train and prepare students to be able to master and understand the concept of an Electromagnetic Control Circuit. In the Ministerial Regulation No. 41 of 2007 states that the learning process on each unit of primary and secondary education should be interactive, inspiring, fun, challenging, and motivating learners to actively participate and provide enough space for innovation, creativity and independence according to their talents, interests, and physical and psychological development of learners. The ministerial regulation shows the active role of students in learning is a necessity (Attard, A., Di Iorio, E., Geven, K., \& Santa, R. 2010). This requires learning process performed teachers should be oriented towards student activities (Biggs, J. B. 2011; Xie, Y., Ke, F., \& Sharma, P. 2008).

Based on observations conducted in SMK Muhammadiyah I Padang on subjects OECS is obtained information that the learning process is still directed at the active role of students in learning. The learning process is done tends to be teacher centred. Similarly happened in class into two areas of expertise in electrical power engineering that looks less active during the learning process this was due to lack of students' understanding of the subject matter. The learning process is less effective that it became one of the causes of low student learning outcomes (Stevens, D. D., \& Levi, A. J. 2013; Hativa, N. 2001). Most of the students do not reach the minimum completeness criteria (MCC) set by the school of 80 . Percentage of completeness was $31.03 \%$ of class A and class B completeness percentage is $38.09 \%$. This suggests that the ability of students in the subjects operate the electromagnetic control system is still low.

To achieve these subjects, it would require an optimization study in an effort to improve student learning outcomes and can make students active in finding concepts and build understanding of the subject matter presented by the teacher (Biggs, J. B. 2011; ). It is always a possible need in the application of learning methods are good and right. One of the methods that can be applied in subjects OECS is a method of Guided Discovery Learning Guided Discovery Learning method is a method of teaching that promotes active learning that emphasizes the importance of understanding in a discipline. According to J. Richard (in Roestiyah, 2008) argues that discovery learning is "a way of teaching that involves students on the process of mental activity through brainstorming, discussions, seminars, reading his own and tried it myself, so that children can learn on their own". Meanwhile Sudjana (2011) revealed in discovery learning "teacher role more places itself as mentors or leaders of learning and facilitator of learning". This method requires students to take an active role in the learning process, independent and directly involved in finding the concepts and principles of learning.

Hosnan (2013) states that the main characteristics of the study finding that "(1) to explore and solve problems to create and combine, and generalize knowledge, (2) students centred, (3) activities to incorporate new knowledge and knowledge that already exists ". While learning with Guided Discovery Learning methods (Suprihatiningrum, 2012) has advantages: (1) Develop intellectual potential. (2) To help students to be more independent, able to orient themselves and take responsibility for their own learning. (3) The students can be actively involved in listening, speaking, reading, seeing, and thinking. (4) Retain memory".

Judging from the characteristics and advantages (Rammelt, U., \& Reinhard, G. 1994; Culyer, A. J. 2012), the application method of guided discovery learning, especially on the subjects of OECS at understanding the operating control system electromagnetic topics considered very well be applied for topics that are both theoretical and much use of learning theories such as the concepts of control circuits electromagnetic must be found and mastered by students so that students can be directed to afford a more active role during the learning process.

According to Shah (2014) the procedures to be implemented in the learning activities guided discovery learning is as follows: "(1) the stimulus, at this stage the teacher gives a stimulus to students in the form of questions or encourages students to observe the images and read books about the material. (2) The 
problem statement, this stage provides an opportunity for students to identify as many issues relevant to teaching materials and then formulate it in the form of a hypothesis. (3) Data Collection, teachers at this stage provide an opportunity for students to gather information. (4) Data processing, process data which have been obtained by the students carefully. (5) Verification, conduct a careful examination to prove the validity to the data obtained by students under the guidance from a teacher. (6) Generalization, teachers with students held a conclusion and findings obtained.

The application of learning methods Guided Discovery Learning methods is expected student to be a master lesson in the lesson of Basic Competence to comprehend the OECS Operating Data Electromagnetic Control System.

\section{Method}

The research is a quasi-experimental (Campbell, D. T., \& Stanley, J. C. 2015; William R.. Shadish, Cook, T. D., \& Campbell, D. T. (2002) research design using one group pre-test-post test (Parry, K. W., \& Sinha, P. N. 2005; Shek, D. T., \& Sun, R. C. 2012). According to Sugiyono (2009) "the results of treatment with one group pre-test-post-test design can be determined more accurately, because it can be compared to the situation before being treated". This study uses a Guided Discovery Learning to improve student learning outcomes group A in SMK Muhammadiyah 1 Padang. The design of this study can be seen in the following table.

Table 1 Design research

\begin{tabular}{ccc}
\hline Pretest & Treatment & Posttest \\
\hline 01 & $\mathrm{X}$ & 02 \\
\hline
\end{tabular}

Subjects were students of the second year in SMK Muhammadiyah 1 Padang enrolled in the academic year 2015/2016 consist of Group A, total 26 students and Group B amount to 20 students. Selection of study subjects were randomized after it emerged that the ability of the two classes does not differ statistically by using t-test analysis.

Based on the t-test of the value of the pre-test showed that $t<t$ table or $0.586<2.0168$. This shows that there is no significant difference to the ability of the two classes, and election results randomly generated Group A as an experimental class.

The instrument of this research is an objective test that has tested the validity, reliability, level of difficulty of questions and distinguishes matter. Data were collected by using achievement test in the form of objective test consisting of question's pre-test and post-test. The data obtained were analyzed using the chi-square formula used to determine the distribution of student learning outcome's data, whether the data is normally distributed or not. An indication of the increase can be observed in pre-test and posttest results of each student, by calculating the average value to the class. In this assessment, a matter made pretest and post-test equivalent. Hake (2002) suggested that the Improvement of learning outcomes can be analyzed using the gain score.

Table 2 Interpretation gain score normalized

\begin{tabular}{ccc}
\hline No & Gain score Normalized & Interpretation \\
\hline $\mathbf{1}$ & $0,7<\mathrm{g}<1$ & High \\
$\mathbf{2}$ & $0,3 \leq \mathrm{g} \leq 0,7$ & Medium \\
$\mathbf{3}$ & $0 \leq \mathrm{g} \leq 0,3$ & Low \\
\hline
\end{tabular}

(Hake, 2002)

\section{Results and Discussion}

Data Description 
This research data is a score of student learning outcomes Group A SMK Muhammadiyah 1 Padang on subjects OECS. Preliminary data obtained from the results of this study pretest students totaling 26 people. Pre-test scores of students ranged from 40 - 84. While the final data obtained through post-test after the class was treated by applying learning methods Guided Discovery Learning. Post-test scores of students ranged from 64 - 96. The distribution of data from pre-test and post-test values can be seen in the following table.

Table 3 Distribution of the value of the experimental class scores

\begin{tabular}{lcc}
\hline Data distribution & \multicolumn{2}{c}{ experimental class } \\
\cline { 2 - 3 } & Prestest & posttest \\
Average & 61,03 & 83,11 \\
standard deviation & 11,54 & 6,853 \\
\hline
\end{tabular}

Based on Table 3 above showed an increase in the average score results in experimental class. Statistical calculations obtained by the average value of the results of the pre-test is $=61.03$ and standard deviation $(s)=11.54$. The distribution of the frequency data is shown in the following Table Frequency Distribution

Table 4 Distribution of pretest frequencies

\begin{tabular}{ccc}
\hline No & Interval & F \\
\hline $\mathbf{1}$ & $40-47$ & 3 \\
$\mathbf{2}$ & $48-55$ & 6 \\
$\mathbf{3}$ & $56-63$ & 7 \\
$\mathbf{4}$ & $64-71$ & 5 \\
$\mathbf{5}$ & $72-79$ & 3 \\
$\mathbf{6}$ & $80-87$ & 2 \\
& Total & 26 \\
\hline
\end{tabular}

Based on table 4 it can be seen that the highest frequency lies on the score interval 56-63. The distribution of the frequency is shown in the following histogram.

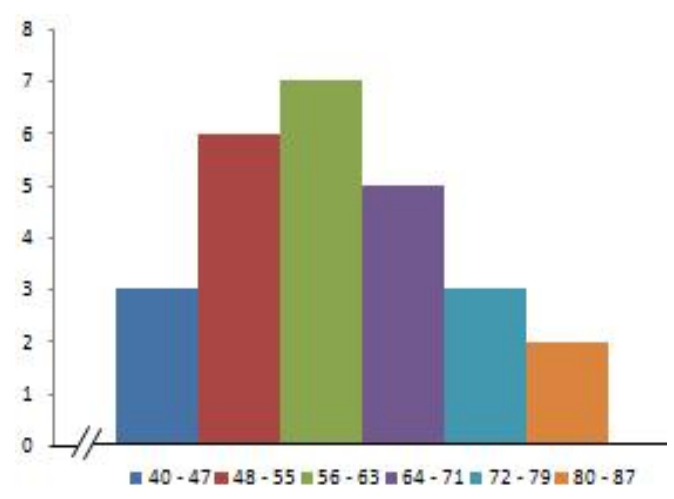

Figure 1 Histogram pre-test score

Based on the histogram the pre-test value describes the MCC's achievement level is still very low where there are still many students whose value is below 80 and only 2 students can achieve MCC score. Table 5 shows the percentage of students who achieved the MCC score.

Table 5 Percentage of number of Students achieving MCC score

\begin{tabular}{cccc}
\hline No & Score & number of students & percentage \\
\hline $\mathbf{1}$ & $<80$ & 24 & $92,3 \%$ \\
$\mathbf{2}$ & $\geq 80$ & 2 & $7,7 \%$ \\
\hline
\end{tabular}

After doing the pretest, the subject of research is given treatment by the learning process using Guided Discovery Learning method and at the end of the learning is given posttest. The statistical calculation 
results show the average result of posttest result is 83,11 and standard deviation $(\mathrm{S})=6,853$. The distribution of frequency data of posttest score can be seen in the following table

Table 6 Frequency distribution of posttest score

\begin{tabular}{ccc}
\hline No & Interval Score & F \\
\hline $\mathbf{1}$ & $64-69$ & 1 \\
$\mathbf{2}$ & $70-75$ & 2 \\
$\mathbf{3}$ & $76-81$ & 7 \\
$\mathbf{4}$ & $82-87$ & 9 \\
$\mathbf{5}$ & $88-93$ & 6 \\
$\mathbf{6}$ & $94-99$ & 1 \\
& Jumlah & 26 \\
\hline
\end{tabular}

According to table 6 , the most frequencies achieved by students at the score interval were $82-87$. The description of the frequency distribution is shown in the following histogram.

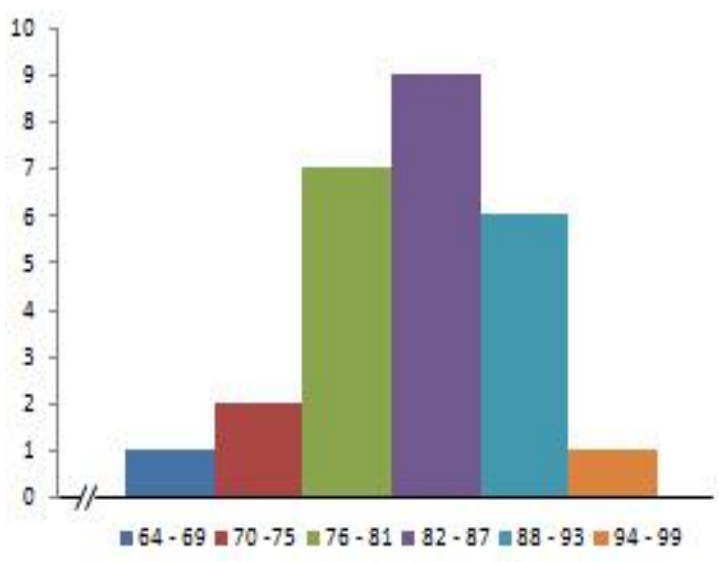

Figure 2 Histogram of the posttest score

Based on the above histogram, the posttest acquisition score has largely exceeded the MCC score established by the school, this means that the students' learning outcomes in the class that were subjected to the study there was a significant increase. Students who have met the MCC score of 23 students and students who have not achieved MCC score of 3 students. Table 7 shows the percentage of students who achieved the MCC score.

Table 7 Percentage of number of students achieving MCC score

\begin{tabular}{cccc}
\hline No. & Score & Number of students & percentage \\
\hline $\mathbf{1}$ & $<80$ & 3 & $11,54 \%$ \\
$\mathbf{2}$ & $\geq 80$ & 23 & $88,46 \%$ \\
\hline
\end{tabular}

\section{Test of Analysis Requirements}

To ascertain whether data from the study subjects were normally distributed, normality tests were performed. Normality test is done by using chi-square test. Testing obtained from comparison of $\mathrm{X}^{2}$ count $<\mathrm{X}^{2}$ table on research subject at level of significance 0,05 at degrees of freedom $(\mathrm{dk})=\mathrm{k}-1=6-1=5$. Calculation of normality test is found in table 8 . 
Table 8 Summary test of normality of pre-test score

\begin{tabular}{ccccc}
\hline Group & $\mathrm{N}$ & $X^{2}{ }_{\text {count }}$ & $X_{\text {table }}$ & Distribution \\
\hline Experiment & 26 & 4,319 & $\mathbf{1 1 , 0 7 0}$ & Normal \\
\hline
\end{tabular}

In table 8 shows that $\mathrm{X}^{2}$ count $<\mathrm{X}^{2}$ table or $4,319<11,070$ this proves that the pretest data obtained from the study subject class is normally distributed. The summary of posttest calculations can be seen in table 9 .

Table 9 Summary of the posttest score normality test

\begin{tabular}{ccccc}
\hline Group & $\mathrm{N}$ & $X_{\text {count }}^{2}$ & $X_{\text {tale }}^{2}$ & Distribution \\
\hline Experiment & 26 & 2,94 & 11,070 & Normal \\
\hline
\end{tabular}

In table 9 shows that the value of $\mathrm{X}^{2}$ count $<\mathrm{X}^{2}$ table or $2.94<11.07$, this proves that the posttest data obtained from the study subject class is normally distributed.

\section{Improving Learning Outcomes}

Improving student learning outcomes were analyzed used gained score by comparing pre-test and posttest scores. The data of the students' learning achievement of the experimental class were obtained by comparing the pre-test and post-test result which was followed by 26 students. After doing the calculation with gain score formula obtained result of average gain score equal to 0,571 . This shows that the average increase in student learning outcomes included in the medium category. Thus it can be explained that student learning outcomes after learning with Guided Discovery Learning method has increased.

\section{Discussion}

Learning outcomes in these OESC subjects are showed after applying the Guided Discovery Learning method of learning. Guided Discovery Learning methods can make students more actively participate in the learning process, improving students' understanding of the material given teachers so that student learning outcomes will increase.

The initial process is to hold a pre-test to see the students' initial ability before being treated. The result of pretest obtained the average value of student learning result of 61,03 . Then tested normality and found that the data is normally distributed. After determining the initial ability then treated by applying Guided Discovery Learning learning for 4 meetings and then given a posttest. The result of data calculation after the treatment obtained the average score of posttest $=83,11$.

The next step is to determine the improvement of student learning outcomes by using gain score and found 2 students or $7.7 \%$ of the total students experienced an increase in the high category, while 24 students or $92.3 \%$ of the total students experienced an increase in the category of being. After analyzing the overall average score obtained 0.571 . This shows the students' learning outcomes are increasing with the average category being.

From the above explanation, learning by applying Guided Discovery Learning method can improve student learning outcomes because of the significant improvement of learning outcomes between pre-test and post-test. The results of this study are reinforced by research conducted by Jufrinaldi (2014), Qorri'ah (2011) and Nanda Febriandika (2011), that after learning by applying Guided Discovery Learning method can improve student learning outcomes.

\section{Conclusions}

Based on the data analysis and discussion it can be concluded that there is an increase in student learning outcomes by applying Guided Discovery Learning method. It is based on the average pre-test students SMK Muhammadiyah 1 Padang for 61.03 with the percentage of students who reached MCC of 7.7\%. After applying Guided Discovery Learning method, the average post-test is 83.11 with the percentage of students reaching MCC equal to $88,46 \%$. Then the student learning outcomes were analyzed using gain score got average increase of 0,571 with medium category. Researchers suggest to the school to motivate teachers to use methods that are varied for the purpose of learning can be achieved well. Toward the teachers of OECS subject to be able to use varied methods in learning one of them is Guided Discovery Learning to improve student learning outcomes. Toward the students to increase awareness and activeness in the classroom so the learning outcomes can increase significantly. 


\section{References}

Arikunto, Suharsimi. (2012). Dasar-dasar evaluasi pendidikan. Jakarta:Bumi Aksara.

Attard, A., Di Iorio, E., Geven, K., \& Santa, R. (2010). Student-Centred Learning: Toolkit for Students, Staff and Higher Education Institutions. European Students' Union (NJ1).

Biggs, J. B. (2011). Teaching for quality learning at university: What the student does. McGraw-Hill Education (UK).

Campbell, D. T., \& Stanley, J. C. (2015). Experimental and quasi-experimental designs for research. Ravenio Books.

Culyer, A. J. (2012). Commodities, characteristics of commodities, characteristics of people, utilities, and the quality of life.

Hativa, N. (2001). Teaching for effective learning in higher education. Springer Science \& Business Media.

Hosnan. (2014). Pendekatan Saintifik dan Kontekstual Dalam Pembelajaran Abad 21. Bogor : Ghalia Indonesia

Meltzer. (2002). Analizing Change/ Gain Score. (Online). Dalam (http://www.physics.indiana.edu. Diunduh 6 Februari 2016).

Nanda Febriandika. (2011). "Penerapan Metode Penemuan Terbimbing dalam Pembelajaran Peralatan Listrik di SMK Bukit Tinggi Tahun ajaran 2009/2010". Skripsi. Padang. UNP.

Parry, K. W., \& Sinha, P. N. (2005). Researching the trainability of transformational organizational leadership. Human Resource Development International, 8(2), 165-183.

Qorri'ah. (2011). Penggunaan metode Guided Discovery Learning untuk meningkatkan pemahaman konsep siswa. Skripsi. UIN Syarif Hidayatullah

Rammelt, U., \& Reinhard, G. (1994). Electrochemical measurements for judging barrier characteristics of organic layers on metals. Dresden, Technische Universitaet, Wissenschaftliche Zeitschrift, 43(2), 41 46.

Riduwan. (2013). Belajar Mudah Penelitian untuk Guru - Karyawan dan Peneliti Pemula. Bandung: Alfabeta.

Roestiyah. (2008). Strategi Belajar Mengajar. Jakarta: Rineka Cipta.

Shek, D. T., \& Sun, R. C. (2012). Promoting psychosocial competencies in university students: evaluation based on a one-group pre-test/post-test design.

Stevens, D. D., \& Levi, A. J. (2013). Introduction to rubrics: An assessment tool to save grading time, convey effective feedback, and promote student learning. Stylus Publishing, LLC.

Sudjana, Nana. (2009). Penilaian Hasil Proses Belajar Mengajar. Bandung: PT. Remaja Rosdikarya.

Sugiyono. (2009). Metode Penelitian Pendidikan. Bandung: Alfabeta.

Suprihatiningrum, Jamil. (2012). Strategi Pembelajaran Teori dan Aplikasi. Yogyakarta : Ar-Ruzz Media.

William R.. Shadish, Cook, T. D., \& Campbell, D. T. (2002). Experimental and quasi-experimental designs for generalized causal inference. Wadsworth Cengage learning.

Xie, Y., Ke, F., \& Sharma, P. (2008). The effect of peer feedback for blogging on college students' reflective learning processes. The Internet and Higher Education, 11(1), 18-25. 


\title{
The implementation of guided discovery learning method to improve student learning outcomes at electromagnetic control system and operation course
}

\author{
Aswardi \\ Universitas Negeri Padang \\ ${ }^{*}$ Corresponding author, $\equiv$ e-mail: aswardi@ft.unp.ac.id
}

\begin{abstract}
This research is triggered by the learning process that is still yet to direct the active role of students learning. Based on the result of observation that the teacher is more dominant in the activity of learning than the students due to the students were lack of understanding towards the subject matter resulted in the lack of activeness of students in the classroom. Based on the background study, it is needed to apply a method of learning that can enhance students' activity and improving the score. One of them by applied the guided discovery learning method. The goal of this research is to know the learning outcome's improvement of the students when using guided discovery learning method on operated Electromagnetic Control System and Operation course in SMK Muhammadiyah Padang. The type of this research is quasi-experimental with one group pre-test post-test design. The population of this research was a second-year student of group one that registered at 2015/2016 academic year which 26 people of students. The instrument of research was objective tests that have been conducted a test on the validity, reliability, the difficulty level and the different index level. The data were analyzed by using gain score test. Based on the result, the student who achieve value of minimum completeness criteria (MCC) before using the guided discovery learning method was $7,7 \%$. While the students who achieve minimum completeness criteria after using guided discovery learning method was $87,46 \%$. Based on gained score test, the scores than the students were increased in Middle Category. So, the implementation of guided discovery learning method can improve student learning outcomes on Electromagnetic Control System and Operation courses.
\end{abstract}

Keywords: Guided Discovery Learning Method, Improving Student Learning Outcomes, Gain Score Test

How to Cite: Aswardi. (2017). The implementation of guided discovery learning method to improve student learning outcomes at electromagnetic control system and operation course. Couns-Edu: International Journal of Counseling and Education, 2(2): pp. 85-91. DOI: https://doi.org/10.23916/0020170210520

\section{Introduction}

Education is essentially very important for requirement and cannot be separated from human life. This means that every human being has the right to education and will be expected to flourish in it. It can be reached formal education, non-formal and informal. Vocational High School as one of the formal educational institutions plays an important role in increasing resources as a nation. 
Secondary vocational schools have close links with business and industry that aim to prepare graduates or mid-level personnel that are ready to face the world of work who have the knowledge, skills and are able to develop a professional attitude in accordance with the specifications of its vocational.

SMK Muhammadiyah 1 Padang also carries out various activities and formal educational activities with the aim of realizing the achievement of its graduates. This school has a variety of programs tailored to the competency skill to be achieved. Program membership is composed of several subjects, including the Operating Electromagnetic Control System (OECS).

OECS is the subject to educate, train and prepare students to be able to master and understand the concept of an Electromagnetic Control Circuit. In the Ministerial Regulation No. 41 of 2007 states that the learning process on each unit of primary and secondary education should be interactive, inspiring, fun, challenging, and motivating learners to actively participate and provide enough space for innovation, creativity and independence according to their talents, interests, and physical and psychological development of learners. The ministerial regulation shows the active role of students in learning is a necessity (Attard, A., Di Iorio, E., Geven, K., \& Santa, R. 2010). This requires learning process performed teachers should be oriented towards student activities (Biggs, J. B. 2011; Xie, Y., Ke, F., \& Sharma, P. 2008).

Based on observations conducted in SMK Muhammadiyah I Padang on subjects OECS is obtained information that the learning process is still directed at the active role of students in learning. The learning process is done tends to be teacher centred. Similarly happened in class into two areas of expertise in electrical power engineering that looks less active during the learning process this was due to lack of students' understanding of the subject matter. The learning process is less effective that it became one of the causes of low student learning outcomes (Stevens, D. D., \& Levi, A. J. 2013; Hativa, N. 2001). Most of the students do not reach the minimum completeness criteria (MCC) set by the school of 80 . Percentage of completeness was $31.03 \%$ of class A and class B completeness percentage is $38.09 \%$. This suggests that the ability of students in the subjects operate the electromagnetic control system is still low.

To achieve these subjects, it would require an optimization study in an effort to improve student learning outcomes and can make students active in finding concepts and build understanding of the subject matter presented by the teacher (Biggs, J. B. 2011; ). It is always a possible need in the application of learning methods are good and right. One of the methods that can be applied in subjects OECS is a method of Guided Discovery Learning Guided Discovery Learning method is a method of teaching that promotes active learning that emphasizes the importance of understanding in a discipline. According to J. Richard (in Roestiyah, 2008) argues that discovery learning is "a way of teaching that involves students on the process of mental activity through brainstorming, discussions, seminars, reading his own and tried it myself, so that children can learn on their own". Meanwhile Sudjana (2011) revealed in discovery learning "teacher role more places itself as mentors or leaders of learning and facilitator of learning". This method requires students to take an active role in the learning process, independent and directly involved in finding the concepts and principles of learning.

Hosnan (2013) states that the main characteristics of the study finding that "(1) to explore and solve problems to create and combine, and generalize knowledge, (2) students centred, (3) activities to incorporate new knowledge and knowledge that already exists ". While learning with Guided Discovery Learning methods (Suprihatiningrum, 2012) has advantages: (1) Develop intellectual potential. (2) To help students to be more independent, able to orient themselves and take responsibility for their own learning. (3) The students can be actively involved in listening, speaking, reading, seeing, and thinking. (4) Retain memory".

Judging from the characteristics and advantages (Rammelt, U., \& Reinhard, G. 1994; Culyer, A. J. 2012), the application method of guided discovery learning, especially on the subjects of OECS at understanding the operating control system electromagnetic topics considered very well be applied for topics that are both theoretical and much use of learning theories such as the concepts of control circuits electromagnetic must be found and mastered by students so that students can be directed to afford a more active role during the learning process.

According to Shah (2014) the procedures to be implemented in the learning activities guided discovery learning is as follows: "(1) the stimulus, at this stage the teacher gives a stimulus to students in the form of questions or encourages students to observe the images and read books about the material. (2) The 
problem statement, this stage provides an opportunity for students to identify as many issues relevant to teaching materials and then formulate it in the form of a hypothesis. (3) Data Collection, teachers at this stage provide an opportunity for students to gather information. (4) Data processing, process data which have been obtained by the students carefully. (5) Verification, conduct a careful examination to prove the validity to the data obtained by students under the guidance from a teacher. (6) Generalization, teachers with students held a conclusion and findings obtained.

The application of learning methods Guided Discovery Learning methods is expected student to be a master lesson in the lesson of Basic Competence to comprehend the OECS Operating Data Electromagnetic Control System.

\section{Method}

The research is a quasi-experimental (Campbell, D. T., \& Stanley, J. C. 2015; William R.. Shadish, Cook, T. D., \& Campbell, D. T. (2002) research design using one group pre-test-post test (Parry, K. W., \& Sinha, P. N. 2005; Shek, D. T., \& Sun, R. C. 2012). According to Sugiyono (2009) "the results of treatment with one group pre-test-post-test design can be determined more accurately, because it can be compared to the situation before being treated". This study uses a Guided Discovery Learning to improve student learning outcomes group A in SMK Muhammadiyah 1 Padang. The design of this study can be seen in the following table.

Table 1 Design research

\begin{tabular}{ccc}
\hline Pretest & Treatment & Posttest \\
\hline 01 & $\mathrm{X}$ & 02 \\
\hline
\end{tabular}

Subjects were students of the second year in SMK Muhammadiyah 1 Padang enrolled in the academic year 2015/2016 consist of Group A, total 26 students and Group B amount to 20 students. Selection of study subjects were randomized after it emerged that the ability of the two classes does not differ statistically by using t-test analysis.

Based on the t-test of the value of the pre-test showed that $t<t$ table or $0.586<2.0168$. This shows that there is no significant difference to the ability of the two classes, and election results randomly generated Group A as an experimental class.

The instrument of this research is an objective test that has tested the validity, reliability, level of difficulty of questions and distinguishes matter. Data were collected by using achievement test in the form of objective test consisting of question's pre-test and post-test. The data obtained were analyzed using the chi-square formula used to determine the distribution of student learning outcome's data, whether the data is normally distributed or not. An indication of the increase can be observed in pre-test and posttest results of each student, by calculating the average value to the class. In this assessment, a matter made pretest and post-test equivalent. Hake (2002) suggested that the Improvement of learning outcomes can be analyzed using the gain score.

Table 2 Interpretation gain score normalized

\begin{tabular}{ccc}
\hline No & Gain score Normalized & Interpretation \\
\hline $\mathbf{1}$ & $0,7<\mathrm{g}<1$ & High \\
$\mathbf{2}$ & $0,3 \leq \mathrm{g} \leq 0,7$ & Medium \\
$\mathbf{3}$ & $0 \leq \mathrm{g} \leq 0,3$ & Low \\
\hline
\end{tabular}

(Hake, 2002)

\section{Results and Discussion}

Data Description 
This research data is a score of student learning outcomes Group A SMK Muhammadiyah 1 Padang on subjects OECS. Preliminary data obtained from the results of this study pretest students totaling 26 people. Pre-test scores of students ranged from 40 - 84. While the final data obtained through post-test after the class was treated by applying learning methods Guided Discovery Learning. Post-test scores of students ranged from 64 - 96. The distribution of data from pre-test and post-test values can be seen in the following table.

Table 3 Distribution of the value of the experimental class scores

\begin{tabular}{lcc}
\hline Data distribution & \multicolumn{2}{c}{ experimental class } \\
\cline { 2 - 3 } & Prestest & posttest \\
Average & 61,03 & 83,11 \\
standard deviation & 11,54 & 6,853 \\
\hline
\end{tabular}

Based on Table 3 above showed an increase in the average score results in experimental class. Statistical calculations obtained by the average value of the results of the pre-test is $=61.03$ and standard deviation $(s)=11.54$. The distribution of the frequency data is shown in the following Table Frequency Distribution

Table 4 Distribution of pretest frequencies

\begin{tabular}{ccc}
\hline No & Interval & F \\
\hline $\mathbf{1}$ & $40-47$ & 3 \\
$\mathbf{2}$ & $48-55$ & 6 \\
$\mathbf{3}$ & $56-63$ & 7 \\
$\mathbf{4}$ & $64-71$ & 5 \\
$\mathbf{5}$ & $72-79$ & 3 \\
$\mathbf{6}$ & $80-87$ & 2 \\
& Total & 26 \\
\hline
\end{tabular}

Based on table 4 it can be seen that the highest frequency lies on the score interval 56-63. The distribution of the frequency is shown in the following histogram.

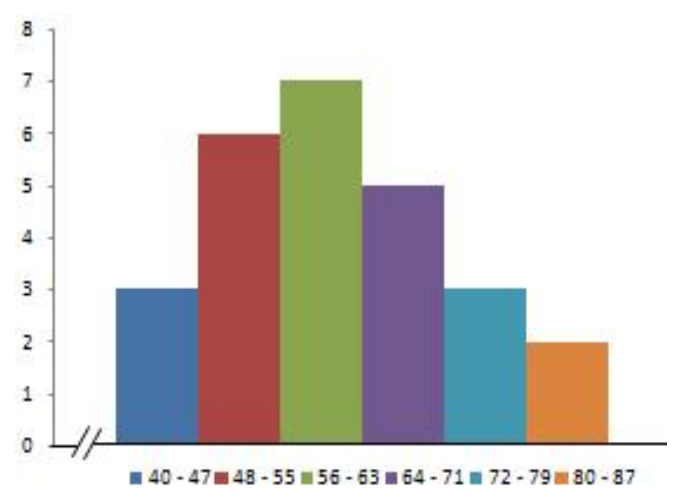

Figure 1 Histogram pre-test score

Based on the histogram the pre-test value describes the MCC's achievement level is still very low where there are still many students whose value is below 80 and only 2 students can achieve MCC score. Table 5 shows the percentage of students who achieved the MCC score.

Table 5 Percentage of number of Students achieving MCC score

\begin{tabular}{cccc}
\hline No & Score & number of students & percentage \\
\hline $\mathbf{1}$ & $<80$ & 24 & $92,3 \%$ \\
$\mathbf{2}$ & $\geq 80$ & 2 & $7,7 \%$ \\
\hline
\end{tabular}

After doing the pretest, the subject of research is given treatment by the learning process using Guided Discovery Learning method and at the end of the learning is given posttest. The statistical calculation 
results show the average result of posttest result is 83,11 and standard deviation $(\mathrm{S})=6,853$. The distribution of frequency data of posttest score can be seen in the following table

Table 6 Frequency distribution of posttest score

\begin{tabular}{ccc}
\hline No & Interval Score & F \\
\hline $\mathbf{1}$ & $64-69$ & 1 \\
$\mathbf{2}$ & $70-75$ & 2 \\
$\mathbf{3}$ & $76-81$ & 7 \\
$\mathbf{4}$ & $82-87$ & 9 \\
$\mathbf{5}$ & $88-93$ & 6 \\
$\mathbf{6}$ & $94-99$ & 1 \\
& Jumlah & 26 \\
\hline
\end{tabular}

According to table 6 , the most frequencies achieved by students at the score interval were $82-87$. The description of the frequency distribution is shown in the following histogram.

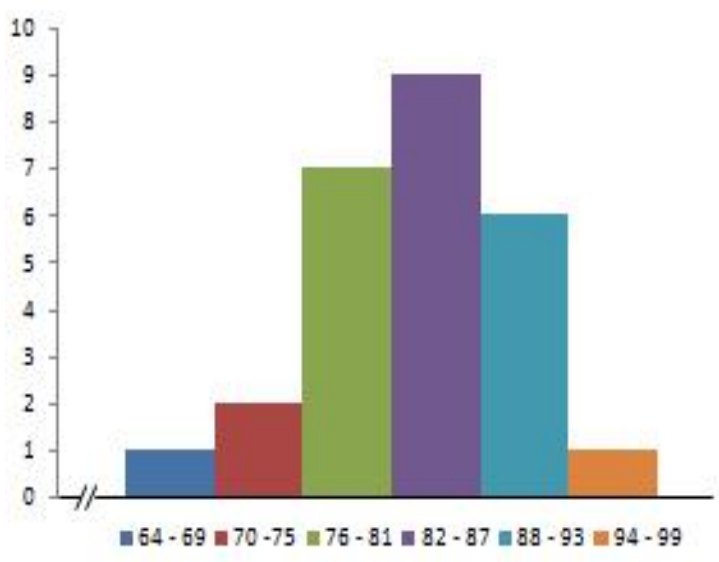

Figure 2 Histogram of the posttest score

Based on the above histogram, the posttest acquisition score has largely exceeded the MCC score established by the school, this means that the students' learning outcomes in the class that were subjected to the study there was a significant increase. Students who have met the MCC score of 23 students and students who have not achieved MCC score of 3 students. Table 7 shows the percentage of students who achieved the MCC score.

Table 7 Percentage of number of students achieving MCC score

\begin{tabular}{cccc}
\hline No. & Score & Number of students & percentage \\
\hline $\mathbf{1}$ & $<80$ & 3 & $11,54 \%$ \\
$\mathbf{2}$ & $\geq 80$ & 23 & $88,46 \%$ \\
\hline
\end{tabular}

\section{Test of Analysis Requirements}

To ascertain whether data from the study subjects were normally distributed, normality tests were performed. Normality test is done by using chi-square test. Testing obtained from comparison of $\mathrm{X}^{2}$ count $<\mathrm{X}^{2}$ table on research subject at level of significance 0,05 at degrees of freedom $(\mathrm{dk})=\mathrm{k}-1=6-1=5$. Calculation of normality test is found in table 8 . 
Table 8 Summary test of normality of pre-test score

\begin{tabular}{ccccc}
\hline Group & $\mathrm{N}$ & $X^{2}{ }_{\text {count }}$ & $X_{\text {table }}$ & Distribution \\
\hline Experiment & 26 & 4,319 & $\mathbf{1 1 , 0 7 0}$ & Normal \\
\hline
\end{tabular}

In table 8 shows that $\mathrm{X}^{2}$ count $<\mathrm{X}^{2}$ table or $4,319<11,070$ this proves that the pretest data obtained from the study subject class is normally distributed. The summary of posttest calculations can be seen in table 9 .

Table 9 Summary of the posttest score normality test

\begin{tabular}{ccccc}
\hline Group & $\mathrm{N}$ & $X_{\text {count }}^{2}$ & $X_{\text {tale }}^{2}$ & Distribution \\
\hline Experiment & 26 & 2,94 & 11,070 & Normal \\
\hline
\end{tabular}

In table 9 shows that the value of $\mathrm{X}^{2}$ count $<\mathrm{X}^{2}$ table or $2.94<11.07$, this proves that the posttest data obtained from the study subject class is normally distributed.

\section{Improving Learning Outcomes}

Improving student learning outcomes were analyzed used gained score by comparing pre-test and posttest scores. The data of the students' learning achievement of the experimental class were obtained by comparing the pre-test and post-test result which was followed by 26 students. After doing the calculation with gain score formula obtained result of average gain score equal to 0,571 . This shows that the average increase in student learning outcomes included in the medium category. Thus it can be explained that student learning outcomes after learning with Guided Discovery Learning method has increased.

\section{Discussion}

Learning outcomes in these OESC subjects are showed after applying the Guided Discovery Learning method of learning. Guided Discovery Learning methods can make students more actively participate in the learning process, improving students' understanding of the material given teachers so that student learning outcomes will increase.

The initial process is to hold a pre-test to see the students' initial ability before being treated. The result of pretest obtained the average value of student learning result of 61,03 . Then tested normality and found that the data is normally distributed. After determining the initial ability then treated by applying Guided Discovery Learning learning for 4 meetings and then given a posttest. The result of data calculation after the treatment obtained the average score of posttest $=83,11$.

The next step is to determine the improvement of student learning outcomes by using gain score and found 2 students or $7.7 \%$ of the total students experienced an increase in the high category, while 24 students or $92.3 \%$ of the total students experienced an increase in the category of being. After analyzing the overall average score obtained 0.571 . This shows the students' learning outcomes are increasing with the average category being.

From the above explanation, learning by applying Guided Discovery Learning method can improve student learning outcomes because of the significant improvement of learning outcomes between pre-test and post-test. The results of this study are reinforced by research conducted by Jufrinaldi (2014), Qorri'ah (2011) and Nanda Febriandika (2011), that after learning by applying Guided Discovery Learning method can improve student learning outcomes.

\section{Conclusions}

Based on the data analysis and discussion it can be concluded that there is an increase in student learning outcomes by applying Guided Discovery Learning method. It is based on the average pre-test students SMK Muhammadiyah 1 Padang for 61.03 with the percentage of students who reached MCC of 7.7\%. After applying Guided Discovery Learning method, the average post-test is 83.11 with the percentage of students reaching MCC equal to $88,46 \%$. Then the student learning outcomes were analyzed using gain score got average increase of 0,571 with medium category. Researchers suggest to the school to motivate teachers to use methods that are varied for the purpose of learning can be achieved well. Toward the teachers of OECS subject to be able to use varied methods in learning one of them is Guided Discovery Learning to improve student learning outcomes. Toward the students to increase awareness and activeness in the classroom so the learning outcomes can increase significantly. 


\section{References}

Arikunto, Suharsimi. (2012). Dasar-dasar evaluasi pendidikan. Jakarta:Bumi Aksara.

Attard, A., Di Iorio, E., Geven, K., \& Santa, R. (2010). Student-Centred Learning: Toolkit for Students, Staff and Higher Education Institutions. European Students' Union (NJ1).

Biggs, J. B. (2011). Teaching for quality learning at university: What the student does. McGraw-Hill Education (UK).

Campbell, D. T., \& Stanley, J. C. (2015). Experimental and quasi-experimental designs for research. Ravenio Books.

Culyer, A. J. (2012). Commodities, characteristics of commodities, characteristics of people, utilities, and the quality of life.

Hativa, N. (2001). Teaching for effective learning in higher education. Springer Science \& Business Media.

Hosnan. (2014). Pendekatan Saintifik dan Kontekstual Dalam Pembelajaran Abad 21. Bogor : Ghalia Indonesia

Meltzer. (2002). Analizing Change/ Gain Score. (Online). Dalam (http://www.physics.indiana.edu. Diunduh 6 Februari 2016).

Nanda Febriandika. (2011). "Penerapan Metode Penemuan Terbimbing dalam Pembelajaran Peralatan Listrik di SMK Bukit Tinggi Tahun ajaran 2009/2010". Skripsi. Padang. UNP.

Parry, K. W., \& Sinha, P. N. (2005). Researching the trainability of transformational organizational leadership. Human Resource Development International, 8(2), 165-183.

Qorri'ah. (2011). Penggunaan metode Guided Discovery Learning untuk meningkatkan pemahaman konsep siswa. Skripsi. UIN Syarif Hidayatullah

Rammelt, U., \& Reinhard, G. (1994). Electrochemical measurements for judging barrier characteristics of organic layers on metals. Dresden, Technische Universitaet, Wissenschaftliche Zeitschrift, 43(2), 41 46.

Riduwan. (2013). Belajar Mudah Penelitian untuk Guru - Karyawan dan Peneliti Pemula. Bandung: Alfabeta.

Roestiyah. (2008). Strategi Belajar Mengajar. Jakarta: Rineka Cipta.

Shek, D. T., \& Sun, R. C. (2012). Promoting psychosocial competencies in university students: evaluation based on a one-group pre-test/post-test design.

Stevens, D. D., \& Levi, A. J. (2013). Introduction to rubrics: An assessment tool to save grading time, convey effective feedback, and promote student learning. Stylus Publishing, LLC.

Sudjana, Nana. (2009). Penilaian Hasil Proses Belajar Mengajar. Bandung: PT. Remaja Rosdikarya.

Sugiyono. (2009). Metode Penelitian Pendidikan. Bandung: Alfabeta.

Suprihatiningrum, Jamil. (2012). Strategi Pembelajaran Teori dan Aplikasi. Yogyakarta : Ar-Ruzz Media.

William R.. Shadish, Cook, T. D., \& Campbell, D. T. (2002). Experimental and quasi-experimental designs for generalized causal inference. Wadsworth Cengage learning.

Xie, Y., Ke, F., \& Sharma, P. (2008). The effect of peer feedback for blogging on college students' reflective learning processes. The Internet and Higher Education, 11(1), 18-25. 